been done, particularly on the pathology of the mamma, by Miss Dawson, and about 1,000 reports on tumour growths were issued; the sections made, together with the material from which they are derived, are preserved and indexed for future reference and research. The death rates of Great Britain and Sweden and the spread of infectious diseases have also been investigated statistically. More than 15,000 examinations of specimens for medical men were carried out.

Society for the Study of Alchemy and Early Chemistry

A Society for the Study of Alchemy and Early Chemistry has been founded in London. It is intended to place the study of alchemy and early chemistry on a broad basis, and for this reason the Council of the Society is desirous of securing the co-operation of scholars in various countries who will contribute to the interests of the Society. It is proposed to hold regular meetings, beginning early in 1936, at which papers will be read and discussed, and to publish a journal in which accounts of the papers will ke given as well as special articles, written contributions by members of the Society and reviews of books. The following council has been elected: Prof. J. R. Partington (chairman), Dr. F. Sherwood Taylor (Editor of the Journal), Gerard Heym (Hon. Secretary), K. de B. Codrington, L. F. Gilbert, Prof. S. R. K. Glanville, Sir Richard Gregory, Dr. E. J. Holmyard, Dr. D. McKie, Dr. L. W. G. Malcolm, Dr. Stephen Miall. Further information can be obtained from the Hon. Secretary, Society for the Study of Alchemy and Early Chemistry, 8 Bream's Buildings, Fetter Lane, London, E.C.4.

\section{International Geological Congress, 1937}

THE organisation committee of the seventeenth session of the International Geological Congress, which will meet in Moscow in 1937, has issued a second circular outlining the scope of the various subjects proposed for discussion. In connexion with the problems associated with the geology of petroleum and coal, it is hoped to make an estimate of the oil reserves of the world and to review the coal resources of the U.S.S.R. and other countries. A discussion of the stratigraphy, igneous cycles, tectonics and mineral deposits of the Pre-Cambrian is proposed. The stratigraphical limits of the Permian System, at present a source of widespread controversy, again comes up for consideration. An attempt is to be made to correlate tectonics, magmatic evolution, ore deposits and geochemistry, and as a further theme a review of the data bearing on these problems with special reference to Asia is proposed. Another geochemical problem is that of the occurrences of rare elements. Geophysical subjects to be discussed include measurement of geological time ; isostasy and anomalies of gravity; terrestrial magnetism; and seismology. Finally, it is hoped that reports will be presented on the history of the various branches of geology. Further particulars may be obtained from the General Secretary, Dr. A. E. Fersman, Sretenka 8, Moscow 10.

\section{Announcements}

Dr. H. S. GASSEN, professor of physiology at Cornell University, New York, has been nominated director of the Rockefeller Institute in succession to Dr. Simon Flexner.

Prof. Yas Kuno, until recently of the Japanese Medical College, Mukden, South Manchuria, and now of the Institute of Physiology, Kyoto Imperial University, Japan, has been appointed a member of the Permanent International Committee of the Physiological Congresses. This is the first time that a representative of Far Eastern physiology has been appointed to the Committee. Prof. Kuno was a pupil of the late Prof. E. H. Starling at University College, London, and is a member of the Physiological Society, Great Britain. He has done very important work on perspiration and body temperature, and has written an excellent book on the subject.

Mr. M. C. LAmb, principal of the Leathersellers' Technical College, will retire from his present position at the termination of the current session, having then attained the age of sixty years. Mr. Lamb has been associated with the College from the time of its opening in 1909, and has had forty years' experience in the teaching of leather technology, having been appointed a demonstrator in the Leather Department of the University of Leeds so far back as 1895. During the period of his occupation of the principalship, the College has been progressively successful, and is now regarded as the most efficient and best equipped of its kind in the world, attracting students from every centre where leather is produced.

Among the awards for 1935 made by the Royal Horticultural Society are the following: Victoria Medal of Honour, Sir Daniel Hall, for his scientific work in connexion with horticulture; Veitch Memorial Medals, Dr. A. D. Cotton, for his services to horticulture, and Prof. E. J. Salisbury, for his book "The Living Garden"; Loder Rhododendron Cup, Mr. A. Rehder, of the Arnold Arboretum, U.S.A., for his work on the genus Rhododendron.

A Discussion on "Probability" will be held by the London Mathematical Society on January 16, at 5 p.m., in the rooms of the Royal Astronomical Society, Burlington House, W.1. The following have promised to take part: Prof. H. Levy, Sir Arthur Eddington, Dr. P. Dienes, Prof. R. A. Fisher, Dr. Harold Jeffreys, Prof. J. B. S. Haldane.

Is ceference to the article on the annual Congress and Exhibition of the British Institute of Radiology in Nature of December 14, p. 960, Dr. J. Read informs us that the first continuously evacuated tube constructed by Lauritzen worked intermittently at $750 \mathrm{k} . \mathrm{v} .$, not $600 \mathrm{k} . \mathrm{v}$. ; also that the Soiland Clinic tube worked at $550 \mathrm{k} . \mathrm{v}$., not $100 \mathrm{k} . \mathrm{v}$. , and that the Clinic has now installed three $200 \mathrm{k} . \mathrm{v}$. constant potential Latour circuits in cascade in place of the cascade transformers. 